\title{
MAPPING VEGETATION ON FERRUGINOUS SUBSTRATES USING ASTER AND GAMMA-SPECTROMETRY IMAGES IN THE IRON QUADRANGLE, MINAS GERAIS
}

Bruno Araujo Furtado de Mendonça ${ }^{2 *} \odot$, Elpído Inácio Fernandes Filho ${ }^{3}$, Luciano Mozer de Assis ${ }^{4} \odot$, Carlos Ernesto Gonçalves Reynaud Schaefer ${ }^{3}{ }^{\circ}$, Pedro Christo Brandão ${ }^{3}$, Maola Monique Faria ${ }^{3} \mathcal{C}_{\text {, Eliana Elizabet }}$ dos Santos $^{3}$ and Aianã Francisco Santos Pereira ${ }^{5}$

\footnotetext{
${ }^{1}$ Received on 20.09.2018 accepted for publication on 25.09.2019.

${ }^{2}$ Universidade Federal Rural do Rio de Janeiro, Departamento de Silvicultura, Seropédica, RJ - Brasil. E-mail: <brunoafmendonca@gmail. com>.

${ }^{3}$ Universidade Federal de Viçosa, Departamento de Solos, Viçosa, MG - Brasil. E-mail: <elpidio.solos@gmail.com>, <carlos.schaefer@ ufv.br>, <pedrocbrandao@gmail.com>,<maolageo@gmail.com> and <liliisantos@hotmail.com>.

${ }^{4}$ Vale S.A, Nova Lima, MG - Brasil. E-mail: <luciano.assis@vale.com>.

${ }^{5}$ Universidade Federal de Viçosa, Departamento de Botanica, Viçosa, MG - Brasil. E-mail: <aianafsp@gmail.com>.

*Corresponding author.
}

\begin{abstract}
The Iron Quadrangle (IQ) region in Minas Gerais is remarkably geobiodiverse, despite a long history of anthropogenic pressures such as mining and urbanization, but still lacks detailed studies on the distribution of its remaining native vegetation in different substrates. In this study, we utilized Advanced Spaceborne Thermal Emission and Reflection Radiometer (ASTER) images, besides Gamma-spectrometry (Gamma) survey data associated with existing geological mapping (GM) and extensive fieldwork, to discriminate and quantify remnants of vegetation on ferruginous substrates in the IQ. The Maximum Likelihood (ML) algorithm was used to classify the vegetation types, thus named: open Rupestrian Field, shrubby Rupestrian Field, Capão Forest, Cerrado stricto sensu, Cerrado Field, Seasonal Forests, Pastures and Reforestation (the latter three regardless of substrate type) associated with the predominant substrates (ferruginous ironstone, phyllites, and quartzite). The use of ASTER images alone did not allow a reliable separation of ferruginous and non-ferruginous substrates, but the integration of all different data (ASTER-ML + Gamma + GM) allowed the provisional mapping of the vegetation associated with ferruginous substrates, potentially ferruginous and non-ferruginous substrates. The resulting map shows that the vegetation on ferruginous and potentially ferruginous substrates cover $8.7 \%$ and $6.9 \%$ of the IQ, respectively. The detailed analysis of the distribution and fragmentation of phytophysiognomies on ferruginous substrates is of great importance for developing strategies to conserve the geobiodiversity of the IQ, and need to be further refined by checking and field mapping by novel approaches.
\end{abstract}

Keywords: Supervised classification; Remote sensing; Aerogeophysical data.

\section{MAPEAMENTO DA VEGETAÇÃO SOBRE SUBSTRATOS FERRUGINOSOS UTILIZANDO IMAGENS ASTER E GAMAESPECTROMETRIA NO QUADRILÁTERO FERRÍFERO, MINAS GERAIS}

RESUMO - A região do Quadrilátero Ferrifero (QF) em Minas Gerais apresenta notável geobiodiversidade, a despeito de uma longa história de pressões antrópicas (mineração, urbanização), mas ainda carece de estudos detalhados sobre a distribuição das formações vegetais nos diferentes substratos. No presente estudo, utilizou-se imagens Aster, levantamentos gamaespectométricos (Gama), mapeamentos geológicos existentes e trabalhos de campo, para a discriminação e quantificação dos remanescentes da vegetação sobre substratos ferruginosos e outros no QF. Utilizou-se o algoritmo da Máxima Verossimilhança (MaxVer) para a classificação das tipologias de vegetação associadas aos substratos predominantes (canga-ferruginosos, filitos e quartzitos), assim 


\begin{abstract}
denominados: Campo Rupestre Aberto, Campo Rupestre Arbustivo, Capão Florestal, Cerrado Stricto Sensu, Campo Cerrado, Florestas Estacionais, Pastagens e Reflorestamentos, sendo os três últimos não discretizados quanto ao substrato. A utilização das imagens Aster apenas não permitiu uma separação confiável de substratos ferruginosos dos não ferruginosos, sendo necessária a utilização de produtos de processamento de dados Gama e de geologia. A integração entre as bases de informação (Aster-MaxVer + Gama + geologia) permitiu o mapeamento da vegetação associada a três tipos de substratos: ferruginoso, potencialmente ferruginoso e nãoferruginoso. O mapeamento revelou que a vegetação sobre substrato ferruginoso e potencialmente ferruginoso recobrem, respectivamente, $8,7 \%$ e 6,9\% no QF. Estes dados preliminares inéditos permitem análises mais detalhadas do padrão de distribuição e fragmentação das fitofisionomias sobre substratos ferruginosos, com grande importância para as estratégias de conservação da geobiodiversidade do QF, e necessitam de checagens de campo e reconhecimento da vegetação, por meio de técnicas inovadoras.
\end{abstract}

Palavras-Chave: Classificação supervisionada; Sensoriamento remoto; Dados aerogeofísicos.

\section{INTRODUCTION}

The Iron Quadrangle (IQ) region has a remarkable geobiodiversity (Fernandes, 2016) but lacks detailed mapping of its vegetation formations. Such mapping could provide technical support for decision-making regarding the conservation of remaining forest and Ferruginous Rupestrian Grassland formations. The region suffers from strong anthropogenic pressures on native ecosystems, mainly as a result of mining and urbanization (Jacobi et al., 2007).

In the mountainous regions, Lateritic Rupestrian Fields, also termed Ferruginous Rupestrian Fields (or Grasslands), or "canga vegetation," develop on ferruginous substrates (Vincent, 2004; Viana and Lombardi, 2007). These unique ecosystems, colonized by specialist plants adapted to oligotrophic environments, are capable of tolerating a number of severe environmental filters, such as shallow soils, severe water deficits, low fertility, high oxidized iron concentrations, and low water retention, as well as large daily thermal amplitudes, frequent fires, high sun exposure, and constant winds (Vincent, 2004; Jacobi et al., 2007; Schaefer et al., 2016). The vegetation shows several anatomical, morphological, physiological, and reproductive adaptations that allow it to survive in these environments (Alves and Kolbek, 1994).

The plant communities in the IQ vary as a function of the substrate type, so that the spectral attributes of soils and surface rocks, in some cases, may assist in mapping the vegetation. Remotesensing techniques, by identifying subtle changes in vegetative cover, can enable the identification of changes in substrate conditions, establishing the rock-soil-vegetation association (Almeida Filho, 1984). The advent of Advanced Spaceborne Thermal Emission and Reflection Radiometer (ASTER) sensor images has enabled discrimination of geological as well as vegetation targets (Lima et al., 2005; Gil et al., 2014). Some studies (Rouskov et al., 2005; Rajendran et al., 2011) used satellite sensors (Landsat Thematic Mapper and ASTER-Terra) for the identification and discrimination of iron-rich deposits through the composition of multispectral indexes. However, this technique becomes limited when such regions are vegetated, which minimizes the effects of the energy reflected by the ferruginous substrates.

Additionally, the gamma-spectrometric (Gamma) data obtained by aerogeophysical surveys enables the elimination of the effects of vegetation cover and the direct discrimination of ferruginous substrates by inferences regarding the geochemical characteristics of the rocks. Also, Gamma spectrometry responds to concentrations of potassium $(\mathrm{K})$ radioisotopes, uranium (U) and thorium (Th) series radioisotopes. In rocks and soils; these concentrations are directly proportional to the intensity of the gamma radiation emitted by their radioactive decay (Wilford et al., 1997; Santos et al., 2008), and are frequently associated with the geochemical signature of substrates. This allows, for example, the separation of ferruginous and nonferruginous substrates, with different geochemical compositions. However, the use of Gamma data has some limitations in terms of distinguishing certain substrates based on their similar responses, unresolved radioactive barriers, or differences in soil moisture; therefore, these data should be used with caution, and preferably combined with all available information (Wilford et al., 1997) in regolith studies.

\title{
Revista Árvore 2019;43(4):e430406
}


In this sense, this work aimed to apply remotesensing techniques associated with geological data (Lobato et al., 2005) with ASTER images and Gamma data to discriminate vegetation remnants on ferruginous substrates and other substrates, in the IQ region.

\section{MATERIALS AND METHODS}

\subsection{Study area}

The IQ is located in central Minas Gerais, with $7,800 \mathrm{~km}^{2}$ in area. All procedures were conducted considering a 5-km buffer from the IQ limits (Figure 1). According to a geological cartography by Lobato et al. (2005), approximately $6.4 \%$ of the IQ consists of iron-rich formations (ferruginous substrates) that are associated with generally shallow soils, where a predominant rupestrian vegetation cover ranges from field to cerrado to upper montane forest. A range of characteristic soils can be found in these areas, showing great landscape and geoenvironmental diversity with the occurrence of a ferruginous substrate (Schaefer et al., 2008, Schaefer et al., 2016).

The denomination "ferruginous substrate," in this study, is broad and more comprehensive than the word "canga", and comprises a range of substrates (fresh rock, altered rock, sedimentary cover, canga, and soils) associated with the following lithotypes in the

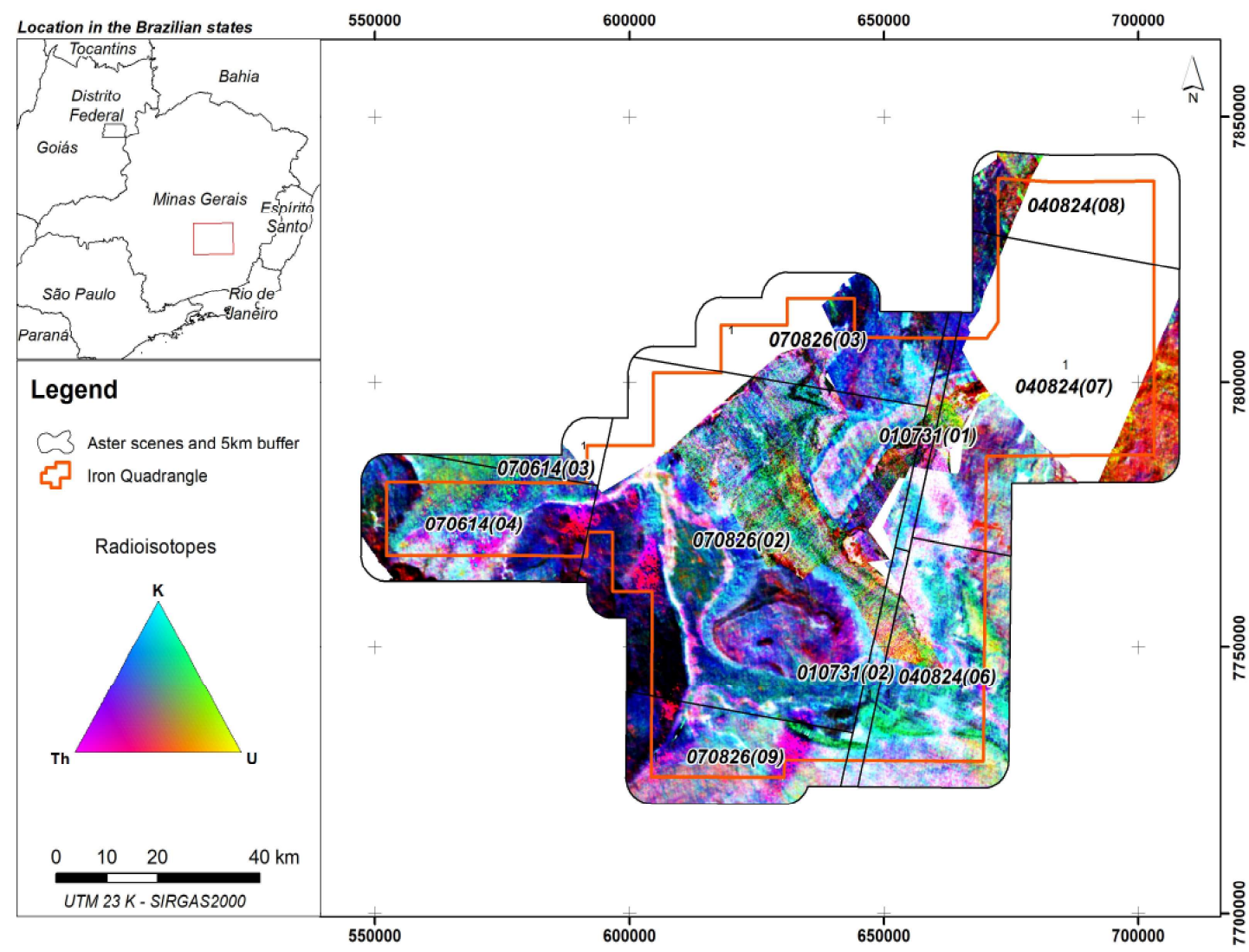

Figure 1 - Limits of the Iron Quadrangle. ASTER image scenes (with the respective date and numeration: YYMMDD(XX)) and ternary image (CMYK) of the radioisotopes $\mathrm{K}(\mathrm{C})$, eTh $(\mathrm{M})$ and eU (Y) of the gamma-ray image.

Figura 1 - Limites do Quadrilátero Ferrífero, cenas das imagens Aster (com as respectivas datas e numeração: AAMMDD $(X X)$ ) e imagem ternária (CMYK) dos radioisótopos $K(C)$, eTh $(M)$ e e $U(Y)$ da gamaespectometria. 
geological map (Lobato et al., 2005): canga, detritallateritic cover, , iron oxide supergene concentrations, hematite bodies, ferruginous dolomites, iron formations, hard hematite, itabirite, dolomitic itabirite, laterite and ferruginous detritus, hard hematite lenses, magnetite, high content iron ore, hematite ore, residual lateritic soil, and associated colluvium and eluvium. However, these lithotypes may occur as secondary component in non-ferruginous geological units, so that the term "ferruginous substrate" is not limited to the delineation of the aforementioned lithotypes.

\subsection{Pre-processing of ASTER images}

Ten ASTER scenes were used, covering the $5-\mathrm{km}$ IQ buffer (Figure 1). ASTER bands 1 to 9 were those processed comprising the visible and near-infrared (VNIR) and shortwave infrared (SWIR) wavelengths. The SWIR bands, with a 30-m spatial resolution, were resampled using the nearest neighbor method to $15 \mathrm{~m}$ for compatibility with the VNIR bands $(15 \mathrm{~m})$. The images were georeferenced from terrestrial control points and orthorectified GeoEye images; the final data were projected in zone $23 \mathrm{~K}$ SIRGAS2000 UTM. ASTER images were then converted to radiance values based on the maximum and minimum radiance values of each band. These procedures were performed using ArcGIS 10 software. Then, the Fast Line-of-sight Atmospheric Analysis of Hypercubes (FLAASH) method of the ENVI 5.0 software was used for the atmospheric correction of the ASTER images.

\subsection{Supervised classification}

In addition to bands 1 to 9 of the ASTER images, multispectral indexes were included in the supervised classification, in which the following band ratios were considered to show certain spectral patterns. 1) To show areas with ferruginous substrates, the red-greenblue (RGB) band composition $\mathrm{R}=$ band $2 /$ band $1, \mathrm{G}=$ band $4 /$ band 3 , and $B=$ band $4 /$ band 5 (Rouskov et al., 2005), was used and 2) to aid in vegetation mapping, the Normalized Difference Vegetation Index (NDVI) was used ((band 3 - band 2) / (band $3+$ band 2)) (Rouse et al., 1974). The Maximum Likelihood algorithm (ML) was used and the following vegetation cover classes were separated and subdivided as a function of the substrate type (ferruginous, quarzitic, and phyllitic): Open Rupestrian Field (ORF), Shrubby Rupestrian Field (SRF), Capão Forest (CF), Cerrado Field (CF), and Cerrado Stricto Sensu (CSS). Training and validation samples were collected from all phytophysiognomies based on geological data (Dorr, 1969; Lobato et al., 2005) and associated with the following substrates: ferruginous, quarzitic, or phyllitic (including serpentinites, metabasalts, and shales).

A large part of the area, totaling 894 control points, was covered to collect training and validation samples using a Garmin 60CSx Global Positioning System receiver. In areas of difficult access, samples were collected as field truths based on the interpretation of high-resolution images (GeoEye) of the Native Vegetation Coverage Map of the State of Minas Gerais (Scolforo et al., 2006) and through queries to the Google Earth image bank. Additionally, samples were collected in regions where the following vegetation classes had no association with lithology: lakes, pastures, and reforestation (Eucalyptus and/or Pinus). Training and validation samples were collected in a polygon format consisting of 1,152 and 775 polygons, respectively. Classes of urban areas and areas influenced by mining were not included in the supervised classification and were overlapped after final processing via manual mapping over GeoEye images.

To evaluate the classification accuracy, validation samples were used and the Kappa index and Global Accuracy were calculated. The Kappa index is a statistic that measures the agreement between field truths and a classified map, noting the map's legitimacy (Congalton, 1991). These values were classified as proposed by Monserud and Leemans (1992). From only the training samples, the Kappa index was evaluated for all band and index combinations to identify the influence of each band or index on the classifier settlement. In addition, following the classification, 40-pixel ( 1-ha) groupings were eliminated and replaced by the most representative neighboring pixels. For all these operations, ArcGIS 10 software was used.

\subsection{Gamma-spectrometry Survey}

Continuous surfaces were generated through interpolation for data enhancement using the minimal curvature algorithm of the radioisotopes $\mathrm{K}$, eTh, and $\mathrm{eU}$ to highlight the lateritic covering and colluvium of ferrous formations (Boyle, 1982; Wildford et al., 1997). Ternary radioisotopic images were also generated using the $\mathrm{C}(\mathrm{K}) \mathrm{M}(\mathrm{eTh}) \mathrm{Y}(\mathrm{eU}) \mathrm{K}$ color scale. The ternary Gamma image was cropped to the 5-km IQ buffer (Figure 1) and an unsupervised classification was performed using the IsoCluster method resulting in 10

Revista Árvore 2019;43(4):e430406 
classes. Then, the classes were superimposed onto the available survey geological units (Lobato et al., 2005) and correspondence with the ferruginous and nonferruginous substrates was visually assessed, allowing the image to be reclassified from 10 to only 2 classes by grouping. Thus, the classes obtained during the Gamma analysis were used to complement and validate the separation of ferruginous and non-ferruginous substrates from the phytophysiognomic classes obtained from the classification of each ASTER scene. These procedures were performed using the ArcGIS 10 software.

\subsection{Geological Data}

From the available IQ geological map (Lobato et al., 2005), two additional characteristics were processed and used for data refinement and integration as follows: 1) Geological units with subordinate ferruginous formations: these do not correspond to the actual ferruginous substrates, but show inclusions of banded iron formations, represented by the following geological units: the Quebra Osso Group, Nova Lima Group (Catarina Mendes, Córrego da Paina, Córrego do Sítio, Mestre Caetano, Mindé, Morro Vermelho, Ouro Fino and Santa Quitéria Units), Caraça Group (Batatal Formation), Piracicaba Group (Cercadinho Formation and Fecho do Funil Formation), Sabará Group, Itacolomi Group (Santo Antônio Formation and Itacolomi Facies Units), and Cambotas Formation; detritic-lateritic cover unit (Lobato et al., 2005). 2) Excluded geological units with no Fe-rich formations: which refer to geological formations without the presence of banded iron formations, used as references to erroneously reclassify the mapped areas as ferruginous substrates. These were the Bação Complex, Belo Horizonte Complex, Bonfim Complex, Caeté Complex, Guanhães Complex, Santa Bárbara Complex, Caraça Group (Moeda Formation, only the core area of Caraça Mountain), Gnaisse Souza Noschese Unit, Granito Borrachudos Unit, Granito Peti Unit and Rocha Intrusiva Unit (Lobato et al., 2005). This filter was mainly used for areas where there was no Gamma data (Figure 1), i.e. the north-northwest and north-northeast regions of the study area.

\section{RESULTS}

\subsection{Supervised classification and validation}

Scene 070826 (02), which covers most of the IQ (Figure 1) and has no cloud cover, was used as a reference for the supervised classification. It was the basis for proposing the best band combinations and multispectral indexes for the Kappa index evaluation. Classification was performed considering all combinations of individual bands and multispectral indexes comprising the best Kappa indexes. Thus, six ASTER bands comprising the best Kappa indices - namely bands 1, 2, 3, 4, 6, and 7 - were selected. ASTER sensor bands 5, 8, and 9 were not included because they did not provide combinations with high Kappa indexes. Band ratios were also selected to show ferruginous substrates according to Rouskov et al. (2005) and the NDVI. The band 4/band 5 ratio, suggested by Rouskov et al. (2005), did not change the Kappa index value, thereby also showing that it provided no contribution to the classification. Thus, this was the only ratio not adopted for the other scenes.

Thus, by evaluating the confounding matrix of the reference scene, it was observed that, in general, the Ferruginous Rupestrian Fields (Open and Shrubby) were more spectrally separated from the Rupestrian Fields compared to that of the other lithologies, that is, they were better identified. In this regard, a cluster was proposed in which the phytophysiognomies on ferruginous substrates were maintained and the phytophysiognomies on non-ferruginous substrates were grouped (quartzites and phyllites), which improved the Kappa index in all scenes. According to Monserud and Leemans (1992), Kappa values obtained for the final classification of this grouping were considered reasonable, good, or very good except for those scenes with lower spatial expression (Table 1 and Figure 1). For the final analysis of the supervised classification, the Kappa index was calculated through the validation samples for the entire study area considering only the

Table 1 - Kappa indices and overall accuracy for each scene considering all classes and groupings.

Tabela 1 - Índices Kappa e exatidão global para cada cena considerando todas as classes e o agrupamento.

\begin{tabular}{llc}
\hline Scenes & \multicolumn{2}{c}{$\begin{array}{c}\text { Kappa Indexes/ } \\
\text { Global Accuracy }\end{array}$} \\
\cline { 2 - 3 } & All classes & Groupings \\
\hline $070826(02)$ & $0.17 / 0.31$ & $0.46 / 0.50$ \\
$070826(03)$ & $0.52 / 0.58$ & $0.61 / 0.65$ \\
$070826(09)$ & $0.44 / 0.51$ & $0.60 / 0.64$ \\
$070614(03)$ & $0.50 / 0.57$ & $0.62 / 0.65$ \\
$070614(04)$ & $0.13 / 0.30$ & $0.53 / 0.58$ \\
$040824(06)$ & $0.79 / 0.81$ & $0.75 / 0.78$ \\
$040824(07)$ & $0.83 / 0.85$ & - \\
$040824(08)$ & $0.94 / 0.95$ & $0.40 / 0.47$ \\
$010731(01)$ & $0.26 / 0.38$ & $0.36 / 0.42$ \\
$010731(02)$ & $0.07 / 0.19$ & \\
\hline OBS: Scenes 040824 (07) and 040824 (08) have vegetation classes only on
\end{tabular}

ferruginous substrates and on quartzites; thus, no grouping is necessary. 
vegetation samples on ferruginous and non-ferruginous substrates. The final Kappa index obtained was 0.61 and the overall accuracy was 0.64 , showing good agreement between the field truths and classified map according to Monserud and Leemans (1992).

\subsection{Integration of data}

The integration of ML classification data with Gamma and geological data allowed the separation of three substrate types: ferruginous, potentially ferruginous, and non-ferruginous. Figure 2 shows a synthesis of data integration used as a differentiating criterion between ferruginous and potentially ferruginous substrates. After integrating the data, areas in the geological map considered as Fe-rich lithotypes and those indicated as ferruginous substrate in the three information sources were considered areas with vegetation on a ferruginous substrate. In a complementary manner, the ferruginous substrate polygons indicated by the integration of the data extrapolating and intercepting the ferruginous lithotypes presented in the geological map (Lobato et al., 2005) had their limits considered as the vegetative cover on the ferruginous substrate.
Areas with a potentially ferruginous substrate were associated with a positive indication in two databases, i.e., the ASTER images and the Gamma classifications; by the ASTER image classification and the geological map as a unit with iron formations at the subordinate level; or in the classification of Gamma data and the geological map as a unit with subordinate iron formations. The areas with a non-ferruginous substrates correspond to the remaining areas indicated and also excluded areas of other geological units such as gneisses, granites, and other associations with no known occurrence of Fe-rich formations, particularly for areas without Gamma coverage (Figure 1).

\subsection{Quantification of vegetation on ferruginous substrates}

The remaining areas of ecosystems developed on a ferruginous substrate cover $676.9 \mathrm{~km}^{2}(8.7 \%)$ of the IQ (Table 2 and Figure 3). The most representative phytophysiognomies are the Capão Forest/Seasonal Forest and the Shrubby Rupestrian Field followed by the Open Rupestrian Field, Cerrado Stricto Sensu, and Cerrado Field, respectively (Table 2). The areas impacted by anthropogenic activity are the urban areas, areas affected
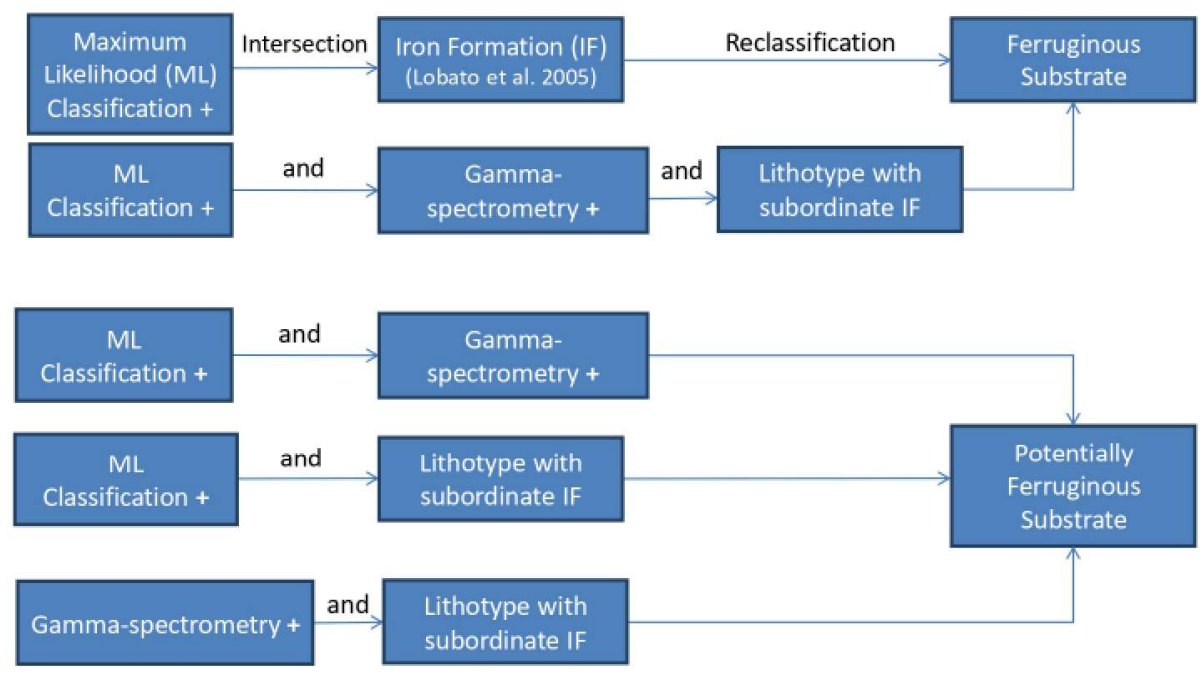

Figure 2 - Flowchart synthesis of the intersection of the information planes. The positive $(+)$ signs indicate the vegetation mapped on ferruginous substrates.

Figura 2 - Fluxograma síntese do cruzamento dos planos de informação. Os sinais positivos (+) indicam a vegetação mapeada sobre substratos ferruginosos.

Revista Árvore 2019;43(4):e430406 
Table 2 - Total and relative area for each phytophysiognomy associated with ferruginous, potentially ferruginous, and non-ferruginous substrates mapped in the Iron Quadrangle, Minas Gerais.

Tabela 2 - Area total e relativa para cada fitofisionomia associada aos substratos ferruginosos, potencialmente ferruginosos e nãoferruginosos mapeadas no Quadrilátero Ferrífero, Minas Gerais.

\begin{tabular}{|c|c|c|c|}
\hline \multirow[t]{2}{*}{ Phytophysiognomies } & \multicolumn{2}{|c|}{ Area } & \multirow[t]{2}{*}{$\%$ to the total } \\
\hline & ha & $\mathrm{km}^{2}$ & \\
\hline \multicolumn{4}{|c|}{ Ferruginous Substrate } \\
\hline Open Rupestrian Field & 10630.67 & 106.31 & $1.36 \%$ \\
\hline Shrubby Rupestrian Field & 15892.22 & 158.92 & $2.04 \%$ \\
\hline Capão Forest / Seasonal Forest & 26454.74 & 264.55 & $3.39 \%$ \\
\hline Cerrado Field & 7336.35 & 73.36 & $0.94 \%$ \\
\hline Cerrado Stricto Sensu & 7371.52 & 73.72 & $0.94 \%$ \\
\hline Subtotal & 67685.50 & 676.86 & $8.67 \%$ \\
\hline \multicolumn{4}{|c|}{ Potential Ferruginous Substrate } \\
\hline Open Rupestrian Field & 7496.91 & 74.97 & $0.96 \%$ \\
\hline Shrubby Rupestrian Field & 10653.05 & 106.53 & $1.36 \%$ \\
\hline Capão Forest / Seasonal Forest & 22855.54 & 228.56 & $2.93 \%$ \\
\hline Cerrado Field & 5008.68 & 50.09 & $0.64 \%$ \\
\hline Cerrado Stricto Sensu & 7500.24 & 75.00 & $0.96 \%$ \\
\hline Subtotal & 53514.42 & 535.15 & $6.86 \%$ \\
\hline \multicolumn{4}{|c|}{ Non-Ferruginous Substrate } \\
\hline Open Rupestrian Field & 33580.87 & 335.81 & $4.30 \%$ \\
\hline Shrubby Rupestrian Field & 58146.75 & 581.47 & $7.45 \%$ \\
\hline Capão Forest & 127220.58 & 1272.21 & $16.30 \%$ \\
\hline Cerrado Field & 46226.14 & 462.26 & $5.92 \%$ \\
\hline Cerrado Stricto Sensu & 37467.56 & 374.68 & $4.80 \%$ \\
\hline Subtotal & 302641.90 & 3026.43 & $38.77 \%$ \\
\hline \multicolumn{4}{|c|}{ Other classes } \\
\hline$\overline{\text { Seasonal Forest/Ombrophylous }}$ & 157172.27 & 1571.72 & $20.13 \%$ \\
\hline Reforestation & 11029.14 & 110.29 & $1.41 \%$ \\
\hline Pasture & 110611.01 & 1106.11 & $14.17 \%$ \\
\hline Urban Areas & 48885.04 & 488.85 & $6.26 \%$ \\
\hline Areas Influenced by Mining & 21414.18 & 214.14 & $2.74 \%$ \\
\hline Lakes & 3132.05 & 31.32 & $0.40 \%$ \\
\hline Clouds & 3246.14 & 32.46 & $0.42 \%$ \\
\hline Cloud shadows & 1305.34 & 13.05 & $0.17 \%$ \\
\hline Subtotal & 356795.17 & 3567.94 & $45.71 \%$ \\
\hline Grand Total & 780636.99 & 7806.38 & $100.00 \%$ \\
\hline
\end{tabular}

by mining, pastures, and reforestation which together correspond to $24.6 \%$ of the total IQ area, proving the great pressure exerted on the natural ecosystems of this region.

\section{DISCUSSION}

The strong anthropogenic pressure on vegetation remmants associated with the ferruginous substrates in the IQ region (Jacobi et al., 2007), which represent extremely important areas for biodiversity conservation in the transition between two large Brazilian hotspots, the cerrado and Atlantic forest (Myers et al., 2000; Fernandes, 2016), justifies detailed studies of the distribution and conservation degree of these phytophysiognomies. In this sense, the use of remote sensing techniques enables identification of these phytophysiognomies and associated substrates (pedological and geological) (Yamaguchi and Naito, 2003; Kalinowski and Oliver, 2004; Rouskov et al., 2005; Rajendran et al., 2011). For some remote orbital sensors obtained through reflectance signals from objects on the Earth's surface (passive sensors), vegetation can interfere or hinder substrate identification, particularly in a closed canopy. However, other sensors, such as gamma spectroscopy, can penetrate vegetation and obtain geochemical data from the upper $30 \mathrm{~cm}$ of soils (Minty, 1997; Wilford et al., 1997).

\section{Revista Árvore 2019;43(4):e430406}




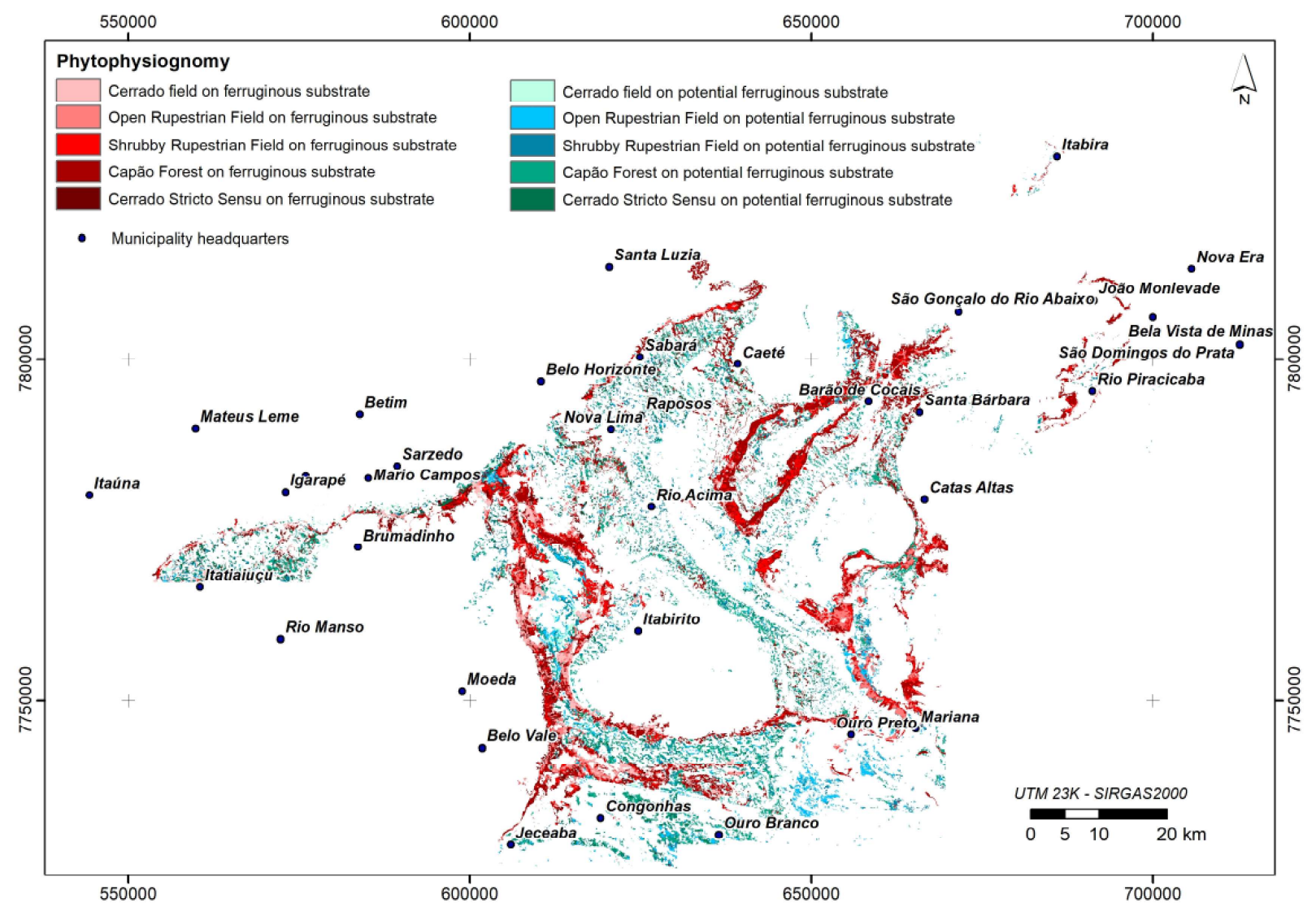

Figure 3 - Final vegetation map of ferruginous and potentially ferruginous substrates of the IQ region.

Figura 3 - Mapa final da vegetação sobre substrato ferruginoso e potencialmente ferruginoso da região do $Q F$.

Regarding the images with spectral data from the ASTER sensor, the combination of bands with the best Kappa indexes - initially calculated with the training samples only-includes six ASTER bands. ASTER sensor bands 5, 8, and 9 were not included because they were not predominant among combinations with higher Kappa indexes. Rowan and Mars (2003) suggest a good spectral separation of lithological categories for ASTER sensor bands 5 to 9 except for ferruginous deposits. The VNIR bands (Bands 1, 2, and 3) have information regarding metal absorption, particularly iron (Adams, 1974; Rowan et al., 1995), and chlorophyll absorption during vegetation photosynthesis (Knipling, 1970). These data corroborate the greater importance of these bands for mapping these phytophysiognomies. In this regard, the grouping of phytophysiognomies in classes on ferruginous substrates and differentiated phytophysiognomies on non-ferruginous substrates (quartzites and phyllites) is also important for the improvement in the Kappa index in all scenes (Table 1), as it also favors the aspects that show phytophysiognomies related to the ferruginous substrates.

In addition to the combination of ASTER bands, the inclusion of band ratios to highlight the ferruginous substrates (Rouskov et al., 2005) and NDVI were also chosen as those with the highest Kappa indexes. The $4 / 5$ band ratio was also noted by Bierwirth (2002) as important in the identification of laterites although it was not influential in this study. NDVI significantly contributes to the identification of different vegetation types as it is influenced by the productivity and photosynthetic dynamics of phytophysiognomies (Rouse et al., 1974; Petorelli et al., 2005).

The definition of areas with greater uncertainties, defined as potentially ferruginous substrates, reinforces

\section{Revista Árvore 2019;43(4):e430406}


the difficulty of mapping these vegetation typologies using spectral data, particularly when associated with specific substrates, as in the IQ region where there are great variations in geological units with different degrees of metamorphism (Lobato et al., 2005). Thus, Gamma data, in addition to assisting geological and pedological surveys (Vasconcellos et al., 1994; Wilford et al., 1997; McBratney et al., 2003; Santos et al., 2008), can be extremely important for mapping phytophysiognomies associated with different substrates.

Therefore, this mapping allows for a more comprehensive analysis of the distribution and fragmentation pattern of the phytophysiognomies on ferruginous substrates which may generate information of great importance for future planning. These data can be combined with more in-depth floristic studies to support future IQ geobiodiversity conservation strategies and provide a more reliable predictability of the impacts caused by anthropogenic actions on these ecosystems. Additional work, such as reducing data using Principal Component Analysis or using more specific remote sensors such as Magnetometry, is required to improve the classification accuracy, particularly for a more precise definition of potentially ferruginous areas. These results should be taken with caution due to confusing identification of potentially ferruginous substrates, and further vegetation mapping combined with field recognition, must be done, employing novel approaches.

\section{CONCLUSIONS}

Selected ASTER sensor bands, band ratios for ferruginous substrates, and NDVI were combined with Gamma and geological data allowed a consistent and reliable vegetation mapping of ferruginous, nonferruginous and potentially ferruginous substrates, the latter with lower confidence level. This mapping shows the complexity of the study region and allows detailed analysis of the distribution and vegetation fragmentation pattern of ferruginous substrates, which is of great importance for conservation strategies in the remarkably geobiodiverse IQ region in Minas Gerais, one of the largest iron mining area worldwide.

\section{ACKNOWLEDGMENTS}

We would like to thank Vale and Bioma Meio Ambiente companies. Financial support from CAPES, CNPq and FAPEMIG is acknowledged.

\section{REFERÊNCIAS}

Adams JB. Visible and near-infrared diffuse reflectance spectra of pyroxenes as applied to remote sensing of solid objects in the solar system. Journal of Geophysical Research. 1974;79(32):4829-4836

Almeida Filho R. Multiseasonal and geobotanical approach in remote detection of albitized-greisenized areas in the Serra da Pedra Branca granitic Massif, Goiás State, Brazil. Economic Geology, 1984;79(8):1914-1920

Alves RJV, Kolbek J. Plant species endemism in savanna vegetation on table mountains (campo rupestre) in Brazil. Vegetatio. 1994;113(2):125-139

Bierwirth PN. Evaluation of ASTER satellite data for geological applications. Consultancy Report to Geoscience Australia; 2002.

Boyle RW. Geochemical prospecting for thorium and uranium deposits. Developments in Economic Geology. 1982;16:71-78

Congalton RG. A review of assessing the accuracy of classifications of remotely sensed data. Remote Sensing of Environment. 1991;37(1):35-46

Dorr JVN. Physiographic, stratigraphic and structural development of Quadrilátero Ferrífero, Minas Gerais, Brazil. Washington: U.S. Government Printing Office; 1969.

Fernandes GW. Ecology and Conservation of Mountaintop Grasslands in Brazil. Switzerland: Springer; 2016.

Gil A, Yu Q, Abadi M, Calado H. Using Aster multispectral imagery for mapping woody invasive species in Pico da Vara Natural Reserve (Azores Islands, Portugal). Revista Árvore. 2014;38(3):391-401.

Jacobi CM, Carmo FF, Vincent RC, Stehmann JR. Plant communities on ironstone outcrops: a diverse and endangered Brazilian ecosystem. Biodivers Conservation. 2007;16:2185-2200.

Kalinowski A, Oliver S. ASTER Mineral Index Processing. Remote Sensing Application Geoscience Australia. Australian Government Geoscience Website: http://www.ga.gov.au/image_cache/ GA7833.pdf; 2004.

\section{Revista Árvore 2019;43(4):e430406}


Knipling EB. Physical and physiological basis for the reflectance of visible and near-infrared radiation from vegetation. Remote Sensing of Environment. 1970;1(3):155- 159.

Lima BEM, Almeida Filho R, Galvão LS, Meneses PR. Avaliação das imagens do sensor ASTER para discriminação espectral de variações faciológicas no granito Serra Branca, Goiás. In: Anais XII Simpósio Brasileiro de Sensoriamento Remoto; 16-21 de abril 2005;Goiânia, Brasil: INPE; 2005.

Lobato LM, Baltazar OF, Reis LB, Achtschin AB, Baars FJ, Timbó MA, et al Projeto Geologia do Quadrilátero Ferrífero - Integração e Correção Cartográfica em SIG com Nota Explicativa. Belo Horizonte: CODEMIG; 2005.

Mcbratney AB, Mendonça Santos ML, Minasny B. On digital soil mapping. Geoderma. 2003;117(1-2):3-52.

Minty BRS. Fundamentals of airborne gamma-ray spectrometry. AGSO Journal of Australian Geology \& Geophysics. 1997;17(2):39-50.

Monserud RA, Leemans R. Comparing global vegetation maps with the kappa statistic. Ecological Modelling. 1992;62(4):275-293.

Myers N, Mittermeier RA, Mittermeier CG, Fonseca GAB, Kent J. Biodiversity hotspots for conservation priorities. Nature. 2000;403:853-845.

Petorelli N, Vik JO, Mysterud A, Gaillard JM, Tucker CJ, Stenseth NC. Using the satellite-derived NDVI to assess ecological responses to environmental change. Trends in Ecology and Evolution. 2005;20(9):503-510.

Rajendran S, Thirunavukkarasu A, Balamurugan G, Shankar K. Discrimination of iron ore deposits of granulite terrain of Southern Peninsular India using ASTER data. Journal of Asian Earth Sciences. 2011;41(1):99-106.

Rouse JW, Haas RH, Schell JA, Deering DW. Monitoring vegetation systems in the great plains with ERTS. In: Earth Resources Technology Satellite-1 Symposium, 3, Washington: NASA.1974;1:309-317.

Rouskov K, Popov K, StoyKov S, Yamaguchi Y. Some applications of the remote sensing in geology by using of ASTER images. Scientific Conference “Space, Ecology, Safety”. 2005;167-173.

Rowan LC, Mars JC. Lithologic mapping in the Mountain Pass, California area using Advanced Spaceborne Thermal Emission and Reflection Radiometer (ASTER) data. Remote Sensing of Environment. 2003;84(3):350-366.

Rowan LC, Bowers TL, Crowley JK, Antón-Pacheco C, Gumiel P, Kingston MJ. Analysis of Airborne Visible-Infrared Imaging Spectrometer (AVIRIS) data of the Iron Hill, Colorado, carbonatite alkalic igneous rock complex. Economic Geology. 1995;90:1966-1982.

Santos ACL, Menezes PTL, Nascimento CTC. Gamaespectrometria aplicada em solo agrícola no noroeste do Estado do Rio de Janeiro. Revista Brasileira de Geofísica. 2008;26(2):181-194

Schaefer CE, Candido HG, Corrêa GR, Nunes JA, Arruda DM. Soils Associated with Rupestrian Grasslands. In: Fernandes G(ed.). Ecology and Conservation of Mountaintop grasslands in Brazil. 1ed.: Springer Intern. Publishing; 2016. p.55-69.

Schaefer CEGR, Mendonça BAF, Corrêa GR, Ribeiro ASS. Solos desenvolvidos sobre canga ferruginosa no Quadrilátero Ferrífero, Minas Gerais. In: Simpósio Afloramentos Ferruginosos no Quadrilátero Ferrífero, Belo Horizonte: Universidade Federal de Minas Gerais. Instituto de Ciências Biológicas. 2008;1:109-121.

Scolforo JR, Carvalho LMT. Mapeamento e Inventário da Flora e dos Reflorestamentos de Minas Gerais. Lavras: UFLA/IEF, 2006.

Vasconcellos RM, Metelo MJ, Motta AC, Gomes RD. Geofísica em levantamentos geológicos no Brasil. Rio de Janeiro: CPRM, 1994.

Viana PL, Lombardi JA. Florística e caracterização dos Campos Rupestres sobre canga na Serra da Calçada, Minas Gerais, Brasil. Rodriguésia. 2007;58(1):159-177.

Vincent RC. Florística, fitossociologia e relações entre a vegetação e o solo em áreas de campos ferruginosos no Quadrilátero Ferrífero, Minas Gerais. [Tese de Doutorado]. São Paulo: Instituto de Biociências da Universidade de São Paulo; 2004.

\section{Revista Árvore 2019;43(4):e430406}


Wilford JR, Bierwirth PN, Craig MA. Application of gamma-ray spectrometry in soil/regolith mapping and geomorphology. AGSO Journal of Australian Geology \& Geophysics. 1997;17(2):201-216.
Yamaguchi Y, Naito C. Spectral indices for lithologic discrimination and mapping by using the ASTER SWIR bands. International Journal of Remote Sensing. 2003;24(22):4311-4323 